\title{
Transmembrane Transport
}

National Cancer Institute

\section{Source}

National Cancer Institute. Transmembrane Transport. NCI Thesaurus. Code C19950.

Any subcellular or molecular process involved in translocation of a biological molecule across a cell membrane from one site or compartment to another. $(\mathrm{NCl})$ 